\title{
LANGUAGE PROBLEMS ENCOUNTERED BY NEWS EDITORS OF THE OVERSEAS SERVICE OF RADIO REPUBLIC INDONESIA
}

\author{
M. Kabul Budiono \\ Program Studi Pendidikan Bahasa Inggris, \\ Fakultas Bahasa dan Seni, Universitas Indraprasta PGRI \\ kabulvoii@gmail.com
}

\begin{abstract}
Abstrak
Radio Republik Indonesia (juga dikenal publik sebagai RRI) sebagai penyiaran publik mengambil prioritas yang sangat tinggi untuk mendapatkan kepercayaan publik melalui program berita yang andal sebagaimana dinyatakan dalam visinya "menjadi sumber berita yang paling dapat diandalkan untuk publik". Untuk mengatasi misi tersebut, RRI memiliki kepedulian yang kuat untuk meningkatkan kemampuan tim jurnalistiknya sehingga mereka akan lebih profesional dalam memproduksi program berita. Namun, tidak ada panduan khusus untuk merancang kursus pelatihan khusus yang berfokus pada penggunaan bahasa Inggris yang tepat. nilai-nilai berita jurnalistik, format program berita, dan prinsip-prinsip penulisan untuk program radio secara umum. Pedoman detail tentang bagaimana menulis dan mengedit buletin berita belum dibahas secara rinci. Tujuannya di sini adalah untuk memetakan masalah yang dipecahkan ketika editor berita harus menulis buletin berita dalam bahasa Inggris. Ada tiga instrumen yang digunakan untuk mengumpulkan informasi yang diperlukan yaitu; wawancara, kuesioner, dan diskusi kelompok terfokus untuk mengetahui kebutuhan para editor berita tersebut. Simpulan tulisan ini adalah untuk membuat pelatihan mencapai tujuannya, instruktur harus menyiapkan materi pelatihan untuk membantu editor meningkatkan kemampuan mereka untuk menulis dan mengedit program berita dengan lebih baik. Materi pelatihan harus sesuai dengan kebutuhan editor dalam praktiknya dan dipelajari dalam silabus.
\end{abstract}

Kata Kunci: editor berita, layanan radio berbahasa Inggris, menulis, menyunting

\begin{abstract}
Radio Republik Indonesia (also publicly known as RRI) as public broadcasting takes very high priority to gain the public trust through it reliable news program as stated in its vision "to be the most reliable news sources for the public." To cope with the mission, RRI has a strong concern to enhance the ability of its journalistic team so they will be more professional in producing news program. There is no such a particular guide to designing specific training course focusing on using appropriate English, journalistic news values, the format of news programs, and the principles of writing for a radio program in general. The detailed guideline of how to write and edit the news bulletin yet to be addressed in detail. The goals here are to map out problems adhered when news editors have to write news bulletins in English. There three instruments employed to gather the necessary information namely; interview, questionnaires, and focused group discussions to know the needs. The conclusion is to make the training reaches its objectives; the instructor has to prepare the training materials to help the editors to improve their capability to write better and edit the news programs. The materials must be suited to the editors' needs and be learned within the syllabus.
\end{abstract}

Keywords: news editor, English radio service, writing, editing 


\section{INTRODUCTION}

Radio as an audio-based medium uses spoken language and sounds to deliver information, education, and entertainment programs. "Unlike television where the pictures are limited by the size of the screen" ("Characteristics of the medium," 2018; Davies \& Elder, 2004), radio's picture created by the spoken words and sounds is by size. Written texts may use more extended space to explore the news while the radio station must be precise. The radio journalist has to be able to choose the words to create appropriate pictures in the listener's mind. To cope with this objective to avoid inaccurate facts, a radio station should employ professional journalist to make its news program not just understandable but accurate and reliable as one of the most important goal to be achieved in broadcasting news and information, not just satisfaction of the listeners.

Radio Republik Indonesia (also publicly known as RRI) as public broadcasting takes very high priority to gain the public trust through it reliable news program as stated in its vision "to be the most reliable news sources for the public." To cope with the mission, RRI has a strong concern to enhance the ability of its journalistic team so they will be more professional in producing news program. From its national channels which use Indonesian, RRI also broadcasts international programs through the Overseas Service (Siaran Luar Negeri) of RRI, named the Voice of Indonesia (VOI) which broadcast seven foreign languages. One of them is the English program under the responsibility of the English Section or English desk. The English desk or section produces news bulletins called VOI Newline, hourly from 03.00 - 09.00 PM every day. Anyhow, to undergo the task to produce good news program, the journalist of English section of the VOI still find the problems of using sufficient and appropriate language. The former head of the VOI Sutrisno Santoso, states the lack of the mastery of English could cause the low quality of the news program, especially daily news bulletins to be broadcast worldwide. There is no such a particular guide to designing specific training course focusing on using appropriate English. The Radio Programmes, a manual book published by the Asia Pacific for Broadcasting Development (Gough, 1982), gives an example of the material to be given to radio journalist in writing and producing news program. This book explains merely journalistic news values, the format of news programs, and the principles of writing for a radio program in general - the detailed guideline of how to write and edit the news bulletin yet to be addressed in detail.

Therefore, RRI needs training materials specialized in filling in the gaps: What are the problems found by the desk editors of the Overseas Services of RRI in editing and writing news bulletin? The goals here are to assist the Overseas Service of RRI to improve the ability of its journalist in producing better programs to gain higher credibility from the audiences.

\section{Principles of Newswriting for Radio}

Martin (1992) gives an overview and examples of the programme design process, target situation analysis, and learner assessment. He gives an overview programme design process of pre-course planning, conduct a dialogue with the client in pre-course negotiation and planning, and need analysis and stakeholder analysis. It also introduces what so-called introduction to target to analysis and classical target situation analysis. The learner assessment is one 
of the priorities to be considered in program design.

Chantler and Stewart (2009)

elaborate on the criteria of radio journalism, namely news reporting, news interviewing, news writing and the format including news bulletins, news editing and the presentation of news programs. About news writing, it clarifies the form of telling the story, building the story, language and grammar, writing technique and style, and radio bulletins essentials. It also underlines the technicalities, law and regulation, and ethics. They underline some principles in news writing for radio which is different from general English and to be considered by the journalist ("Broadcast sentence structure," n.d.; "Lead \& teases," n.d.):

1. Keep it simple. In radio news scripts, simple sentences are best. The journalist will, of course, regularly use compound and complex sentences, but the clarity achieved through the use of simple sentences can rarely be surpassed. Particles in English include the words "moreover," "furthermore," and "however," words that should be avoided in broadcast news writing.

2. Avoid relatives. Relative clauses, which begin with a relative pronoun or adverb such as "who" or "where," provide additional information about a noun in a sentence. Those relative clauses which interrupt the flow of the sentence should not be used in broadcast news writing. In a text communicated visually, a reader has the words on a page or screen to help guide him back to the story after the detour of a relative clause. Listeners do not have such a guide and must rely on the speaker to provide information in readily understood clauses that are concise and uninterrupted.
3. Be active. Use the active voice. Writing sentences with subjects that are doing things and not subject that are merely receiving actions upon them. Do not waste time stating an object's existence (this is what the "there is" construction shows) describe that object doing something. Simple sentences with active verb form the basis of effective writing for radio. All other broadcast news writing techniques are built upon the foundation laid by this type of sentence structure.

4. Avoid repetition. Repetition is the most common mistake made in leads and teases. Listeners understandably come to believe that there is far less news than meets the ear.

5. Keep it fresh. Tenses of the past should be avoided in leads and teases. Present tenses give immediacy and energy to news writing, allowing listeners to feel that they hear about the news as it is taking place. The changing lead shifts the emphasis of the story to a future event, and so the package of lead and tape together remain fresh.

6. Absent antecedent. A frequent error in teases is the use of pronouns with any reference to identify the pronouns. The pronouns' antecedents are absent.

After reviewing some references regarding radio journalism, especially radio news writing, the writer finally concludes that radio news writing is different from general English and to be reckoned English for specific purposes, specifically English for occupational purposes (EOP).

\section{English for Specific Purpose}

Hutchinson and Waters (1987) assume that ESP is a phenomenon that emerges from what they call converging trends, namely the demands of a brave new 
world a revolution of linguistics and focuses on the learner. ESP, according to Hutchinson and Waters (1987), ESP is nearly approached rather than a product. They assume that ESP emerges from a question 'Why does the learner need to learn English?'. 'Learners are seen to have different needs and interest." They presumed that ESP must be focused on the learners and relevant to their needs. However, Dudley and St Johns (1998) underline that the purposes are the starting points which undermine the kind of language to be taught

Different from Hutchinson and Waters, Strevens (1998) emphasizes the distinction of what it is stated as absolute characteristics and variable characteristics. According to Strevens (1998), there are four absolute characteristics. They are: (1) designed to meet the specified need of learner; (2) related in content to particular disciplines, occupation and activities; (3) centered on language appropriate to those activities in syntax, lexis, discourse, semantics, and analysis of the discourse; (4) in contrast with general English. Moreover, the variable characteristics are that ESP may be restricted as to the learning skills to be learned and may not be taught according to any pre-ordained methodology.

However, Robinson (1980) and Huhta, Vogt, Hohnson, Hall, \& Tulki (2013) also agrees that needs analysis is the primacy of ESP. Her definition of ESP is at least based on two keys of defining criteria; normally goal-directed, and a need analysis. She also states the characteristics of ESP are time-limited and taught to adults in homogenous classes. Concerning the work or specialist studies that the students are involved.

Still, the definition, ESP must differ from English for general purposes in term of the purposes, the target audiences, and of course the methodology to be used. "ESP is defined to meet specific needs of the learners and related for specific discipline, and the most important aspect to be considered is that ESP is based on the learners"(Zhu \& Liu, 2014).

\section{Course Design}

When it comes to designing a specific course, there are four points to be addressed regarding ESP (Nunan, 1989, 1991, 1998, 2017; Péter, 2002; Wong \& Nunan, 2011):

1. Being focused on the learners' need, it wastes no time;

2. It is relevant to the learner;

3. It is based on radio journalistic work and norms

4. It is successful in imparting learning;

5. It is more cost-effective than 'General English.'

To cope with those advantages, the course design is the utmost vital step to be considered.

\section{RESEARCH METHOD}

To broadcast its news program one of them for English Section which broadcast 6 hours daily. Disseminating especially to Asia and Europe, English program of the VOI broadcast news bulletin hourly in English prepared and produced by 11 journalists. To cope with the standard of being reliable and credible, that VOI journalist must have a good command of English for broadcasting especially news. Some of the journalist in a preliminary interview also agree on such training to uphold their capability and competency.

\section{Participants}

The audience of the Overseas Service of RRI were chosen randomly and contacted by electronic mails. Two audiences live within the Asian country, and two others are European. The audiences of the Overseas Service of 
RRI usually contact the editors and announcers in Jakarta by email. The writer interviewed and asked five news editors to answer questionnaire distributed to them.

\section{Instruments}

There three instruments employed to gather the necessary information namely; interview, questionnaires, and focused group discussions to know the needs. Anyhow to bridge the gap and to open communication with those informants a rapport is considered very important.

In order to support the data to be valid, the researchers conducted focused group discussion (FGD) after the completion of the questionnaires and interview with some of stakeholders and practitioners. The FGD was recorded, and the results were double-checked with what obtained from the questionnaires.

\section{RESULTS AND DISCUSSION}

The profile of the respondents seen from their language education is as follows: out of five respondents working at the international service, some have attended English Language education through Faculty of Letters and some of them through courses. The respondents attending English Literature education from formal education (university/high learning education) may graduate from English Literature. Next, if seen from the TOFEL scores, there are only two respondents who wrote the TOEFL scores, namely 550 and 590 respectively. The rest of the respondents did not mention the scores. There are two causes to explain this, namely: they have not had the TOFEL test so as they did not know the scores, or the scores are too low so that they did not have the selfconfidence to write it down.
There are five respondents for the questionnaires between 33-35 years-old and have worked at Voice of Indonesia for 6 to 25 years. (see table 1 ).

Table 1 Respondents' Working Time at the International News Service

\begin{tabular}{|l|l|l|}
\hline $\begin{array}{c}\text { Working } \\
\text { Time }\end{array}$ & Frequency & Percentage \\
\hline 6 years & 1 & 20.00 \\
\hline 19 years & 1 & 20.00 \\
\hline 20 years & 1 & 20.00 \\
\hline 23 years & 1 & 20.00 \\
\hline 25 years & 1 & 20.00 \\
\hline Total & 5 & 100.00 \\
\hline
\end{tabular}

As a journalist who has worked for years, certainly, the respondents have had various kinds of journalism training, at least from LPP RRI. The respondents have attended various kinds of journalism training from various institutions. Training on radio journalism in specific issues is peace journalism, international radio journalism, and also investigative journalism. However, if observed, it appears that not all journalists at the international service have had training on basic journalism. Whereas, the training is significant as it lays the necessary knowledge and skills in the field of journalism. Without the necessary knowledge and skills, it would be difficult for a journalist to develop the knowledge further, moreover if he is an editor because an editor should have mastered how to write good news.

What are the problems found by the desk editors of the Overseas Services of RRI in editing and writing news bulletin?

Problems in editing usually focus on two main things, namely problems in substance and writing including the language. The problem in substance is 
whether the news is worth broadcasting and whether the news has been well written with good logic, while knowledge in language relates to whether they master the language which is used in the news writing well.

a. Problem in Language

In language point of view, out of the basic language skills, it seems out of four respondents answering problem in language part, only one respondent said she/he does not have difficulty in language skills. Therefore, it can be said that the respondent has good language skill, at least if seen from three primary language skills, namely grammar, vocabulary, and listening. The rest of the respondents say that they have difficulty listening, grammar, and vocabulary (see Table 2)

Table 2 Language Difficulty

\begin{tabular}{|c|c|c|}
\hline $\begin{array}{c}\text { Language } \\
\text { Problems }\end{array}$ & $\begin{array}{c}\text { Frequ } \\
\text { ency }\end{array}$ & $\begin{array}{c}\text { Percen } \\
\text { tage }\end{array}$ \\
\hline grammar & 1 & 25.00 \\
\hline vocabulary & 1 & 25.00 \\
\hline listening & 1 & 25.00 \\
\hline none & 1 & 25.00 \\
\hline
\end{tabular}

Next, if specifically observed, vocabulary is the most fundamental problems. Respondents say that they have difficulty to (1) find the suitable word when writing the news; and (2) to find words difficult to understand when reading a piece of news or article in English. Such a difficulty is not only applied in the English language as vocabulary always develops so that one is demanded to develop his or her language ability, particularly in new vocabulary.

b. Problems in Writing News Story
Problems in news writing can be seen in two main dimensions, namely how the respondent's knowledge of editorial policy, regulation and media ethics; and editing and writing the news story. Knowledge on editorial is the most essential dimension as the news written depends on the media redaction al policy.

c. Knowledge in editorial policy, regulation and media ethics

For knowledge in editorial policy, all respondents say that they understand the editorial policy of LPP RRI. The problem is only on the respondents' knowledge of what is meant by the LPP (Public Service Broadcasting). As seen in Chart 2, some $60 \%$ of the respondents say they know well what is meant by Public Service Broadcasting, while $40 \%$ of them say they do not understand about the Public Service Broadcasting.

It can be said that respondents' knowledge on the regulation, in this case, Law No 32 the year 2002 on Broadcasting is good. Out of the respondents who answered questionnaires on this part, only one respondent $(25 \%)$ who says that he or she has never read Law on Broadcasting. The rest of them $(75 \%)$ say they have read Law on Broadcasting.

The number of respondents who have read Law on Broadcasting does not have a positive correlation on its derivative regulation. It is proven only one respondent $(25 \%)$ who says that he or she has never read the government's regulation for Public Service Broadcasting. Whereas, the government regulation is much more operational and therefore it also gives technical knowledge of Public Service Broadcasting. 
Knowledge of other regulations is much worse. Out of five respondents, all of them answered this part and only $20 \%$ who say that they have never read regulation on Implementation and Standard Broadcasting Program (P3SPS). The P3SPS regulation is issued by the Indonesian Broadcasting Commission (KPI), and it contains guidelines in broadcasting, both news, and non-news. Unfortunately, not many respondents read the regulations. The P3SPS regulation provides guidelines for electronic news broadcasting. Problems in editing and writing radio news:

1) Understanding basic journalism and editing

Problems in editing and radio news writing can be observed from the respondents' knowledge on their tasks as an editor. Besides, it can be observed from the journalist's knowledge of principles of news writing. Based on the category, all of the respondents' knowledge can be seen in Table 4. Based on Table 4, it can be seen that only one dimension in which the knowledge of the respondents is quite good on what is meant by sound clips. Out of 4 (four) persons answering, 3 (three) persons $(75 \%)$ say that they do not know well about sound clips. The rest do not know. Only one respondent who does not answer, perhaps the respondent who does not answer the question also does not know about sound clips. Based on this data, a journalist of international service has had good knowledge of the principles of news writing even though they have not attended any basic radio journalistic training.

2) Source of News Writing
The research also wants to observe news sources used by the journalists in writing news story. There is more than one answer each, so in total there are 11 chosen. Table 3 shows that live interview is the lowest level of percentage of the news source. On the contrary, online news agency, media online and journalists' reports are sources of news mostly used for news writing.

Table 3 Source of News Writing

\begin{tabular}{|l|c|c|}
\hline $\begin{array}{c}\text { Reference } \\
\text { for writing } \\
\text { news in } \\
\text { international } \\
\text { service }\end{array}$ & Frequency & Percent \\
\hline $\begin{array}{l}\text { Online News } \\
\text { Agencies }\end{array}$ & 3 & 27.27 \\
\hline $\begin{array}{l}\text { Media } \\
\text { Online }\end{array}$ & 3 & 27.27 \\
\hline Interviews & 2 & 18.18 \\
\hline $\begin{array}{l}\text { Journalists' } \\
\text { Reports }\end{array}$ & 3 & 27.27 \\
\hline Total & 11 & 100.00 \\
\hline
\end{tabular}

Next, among the news sources, news from newspaper and interviews has become the most difficult sources for writing news. The difficulties in making the interviews to become news source are logical as an editor has to compose sentences by themselves in writing the news. Meanwhile, for the newspaper as news sources, the format is different from radio format which is briefer to compile them to become short news is not always easy.

3) The most difficult problems as an Editor

Table 4 shows clearly the most challenging thing as an editor. Finding and writing the main facts are the most difficult part. Out of the respondents who answer the 
question, only two respondents $(33.33 \%)$ who say that finding and writing the main facts are the most challenging thing to do as an editor. The rest, in average, the respondents who find it difficult to make a good lead reaches $16.67 \%$, finding and writing in detail is $16.67 \%$, finding and writing the background is $16.67 \%$, and making a conclusion or closing is $16.67 \%$. The high number of respondents who answer finding facts and writing it is the most difficult thing is because most of the respondents have not received basic training on journalism, whereas it is in the basic training that a journalist is taught with what is meant by the facts (journalism). If a journalist has not received any journalism training, he or she will face difficulty.

Table 4 The most difficult thing to do as an editor of international service

\begin{tabular}{|l|c|c|}
\hline $\begin{array}{l}\text { The most } \\
\text { difficult thing to } \\
\text { do (answers } \\
\text { may be more } \\
\text { than 1) }\end{array}$ & $\begin{array}{c}\text { Frequ } \\
\text { ency }\end{array}$ & $\begin{array}{c}\text { Percen } \\
\text { tage }\end{array}$ \\
\hline $\begin{array}{l}\text { Making strong } \\
\text { Radio Lead }\end{array}$ & 1 & 16.67 \\
\hline $\begin{array}{l}\text { Finding and } \\
\text { writing the } \\
\text { main facts }\end{array}$ & 2 & 33.33 \\
\hline $\begin{array}{l}\text { Finding and } \\
\text { writing in detail }\end{array}$ & 1 & 16.67 \\
\hline $\begin{array}{l}\text { Finding and } \\
\text { writing } \\
\text { background } \\
\text { information }\end{array}$ & 1 & 16.67 \\
\hline $\begin{array}{l}\text { Making news } \\
\text { closing }\end{array}$ & 1 & 16.67 \\
\hline None & 0 & 0.00 \\
\hline Total & 6 & 100.00 \\
\hline
\end{tabular}

There are three main things to be noticed, particularly for LPP RRI. Firstly, the journalists have low understanding of broadcasting regulation. It is crucial for LPP RRI to socialize it to the journalists in the International Service. LPP RRI can cooperate with Indonesian Broadcasting Commission (KPI) in socializing P3SPS. The journalists also have lack understanding on Public Service Broadcasting so that training on what is meant by Public Service Broadcasting (PSB) is important as PSB is the new ideology of LPP RRI.

Secondly, one of the problems is the diction in writing news. Therefore, several respondents in the interview say that it is important to have translation training by inviting experienced translators who have experience in translating particularly technical translation.

Next is to organize advanced training on editors. The training should consist of $25 \%$ theory and $75 \%$ practice so that the journalists do have not only cognitive knowledge but also practical skills. The duration of the training is adjusted with the breakdown of the materials of the training. For example, a 3 to 4 day-training consisting of one full day on theory and 2 or 3 days for practice. Every practice is evaluated so that the journalists know skill to be improved.

\section{CONCLUSION}

The English news editors of the Overseas Service of RRI (Voice of Indonesia) still have some language problems. Firstly, even all of the respondents graduated from universities level with English as a major; they still have difficulties in composing a sentence 
as the lead of news bulletins. It has been discussed that writing radio news bulletins are different from general English. Radio news bulletin has its own style what so-called radio journalism genre. On editing and news writing technique, the research found that some of the respondents have problems in finding facts or main substance to be written as a lead of the news. They also still have to learn how to choose a sound clip from the news resources to be produced of what so-called inserted news. Second, helping the editors to enhance their capacity, the Voice of Indonesia need to conduct a special training based on a course framework or blueprint including two objectives. Firstly, to develop an understanding of the principle of radio news editing, and secondly to enhance the skills of rewriting or editing, as well as producing news bulletins. The final conclusion is to make the training reaches its objectives; the instructor has to prepare the training materials to help the editors to improve their capability to write better and edit the news programs. The materials must be suited to the editors' needs and be learned within the syllabus.

\section{REFERENCES}

Broadcast sentence structure. (n.d.). Retrieved from http://newscript.com/sentence.html

Chantler, P., \& Stewart, P. (2009). Essential radio journalism: How to produce and present radio news. London, United Kingdom: Bloomsbury Publishing PLC.

Characteristics of the medium. (2018). Retrieved from http://radioproduction.org/characte ristics-of-the-medium/

Davies, A., \& Elder, C. (2004). The
Handbook of applied linguistics. Blackwell Publishers Inc. https://doi.org/10.1002/978047075 7000.ch7

Dudely-Evans, T., \& St.John, M. (1998). Developments in ESP: A multidisciplinary approach. Cambridge: Cambridge University Press.

Gough, H. (1982). The Radio programme: Planning, producing, presenting: for information, education and entertainment with special emphasis on radio as an educational channel for development support. Kuala Lumpur, Malaysia: Asia-Pacific Institute for Broadcasting Development.

Huhta, M., Vogt, K., Johnson, E., Hall, D. R., \& Tulkki, H. (2013). Needs Analysis for Language Course Design: A Holistic Approach to ESP. Cambridge University Press. Retrieved from https://books.google.co.id/books?i $\mathrm{d}=\mathrm{k} 5$ AP9J9Z8CUC

Hutchinson, T., \& Waters, A. (1987). English for Specific Purposes. Cambridge University Press.

Lead \& teases. (n.d.). Retrieved from http://newscript.com/leads.html

Martin, I. (1992). An invitation to ESP. Singapore: SEAMEO Regional Language Centre.

Nunan, D. (1989). Designing tasks for the communicative classroom... https://doi.org/10.1002/hyp.7223

Nunan, D. (1991). Communicative tasks and the language curriculum. 
TESOL Quarterly. https://doi.org/10.2307/3587464

Nunan, D. (1998). Teaching grammar in context. ELT Journal. https://doi.org/10.1093/elt/52.2.10 1

Nunan, D. (2017). Language learning beyond the classroom. In Faces of English Education: Students, Teachers, and Pedagogy. https://doi.org/10.4324/978131520 5618

Péter. (2002). The Cambridge guide to teaching English to speakers of other languages. R. Carter D. Nunan. ELT Journal. https://doi.org/10.1093/elt/56.1.87

Robinson, P. C. (1980). ESP (English for specific purposes): The present position. Pergamon Press.

Strevens, P. (1998). ESP after twenty years: A re-appraisal. Singapore: SEAMEO Regional Language Centre.

Wong, L. L. C., \& Nunan, D. (2011). The learning styles and strategies of effective language learners. System. https://doi.org/10.1016/j.system.20 11.05.004

Zhu, W., \& Liu, D. (2014). Study on the Theoretical Foundation of Business English Curriculum Design Based on ESP and Needs Analysis. Higher Education Studies, 4(1), 68-74. https://doi.org/10.5539/hes.v4n1 p68 